health. Notwithstanding his blindness, he continued to take great interest in Medical Psychology, and frequently contributed articles to Winslow's Peychological Journal. He had no difficulty in clothing his sentiments in flowing and elegant language. In his paper on Guitean he adrocated the view that he was insane. His articles on "Mad Poets" are pleasant reading.

DANIEL NOBLE, M.D., F.R.C.P.

Dr. Noble was at one time prominently before the public as a writer on Paychological Medicine and allied subjects. It is so long since he wrote any work that he is in danger of being forgotten. His " Elements of Psychological Medicine" possessed no small merit, though severely criticised by the late Professor Laycock in a medical periodical. In "The Brain and its Physiologg," Dr. Noble entered into a minute defence of the phrenological system, and threw fresh life into it by his vigorons style and his able mode of handling it. The most striking and important contribution, however, was his "Mesmerism True-Mesmerism False," which appeared in Forbes's "British and Foreign Medico.Chirurgical Review " in 1845 , and was generally supposed to be from the editor's brilliant pen. At the present day it would probably not command particular attention, and wonld, it is likely, be thought to err on the side of scepticism; but forty years ago it was a bold, though discriminating, advocacy of what was really true in mesmerism, and was entirely free from indulging in the ignorant valgar tirade against everything passing under the name, which at that period disgracefully characterised the treatment of the sabject by the medical journals. In Dr. Noble, Sir John Forbes recognised one of his ablest and most intelligent contributors. Among his other works were "The Human Mind in its Belations with the Brain and Nerrous System;" and "Influence of Manufactures upon Health and Life."

Dr. Noble died at Manchester January 12, aged 75.

\title{
Appointments.
}

Cocks, HoraCr, M.B., C.M.Ed., appointed Junior Assistant Medical Offoer to the Norfolk County Asylum, Thorpe, near Norwich.

Joznston, M., M.R.C.S., L.R.C.P., L.M.Lond., appointed Junior Assistant Medical Officer to the Sussex Cou nty Lunatic Asylum, Haywards Heath.

NokmaN, CoNolly, M.K.Q.C.P.I., F.R.C.S.I., appointed Resident Medical Superintendent to the Monaghan County Lunatic Asylum.

WaLKRR, E. B. C., M.B., C.M.Ed., promoted Senior Assistant Medical Officer to the Sussex County Lunatic Asylum, Hay wards Heath.

W., RTBington, Thos. B., B.A., M.D., T.C.D., appointed Medical Superintendent to the Hants County Asylum, Knowle, Fareham, vice Dr. Manley resigned.

Scholes, R. BatTrRsBY, M.B., C.M.Ed., appointed Inspector of Asylums for the Insane, Queensland. Also Superintendent of the Hospitals for the Insane at Goodna and Sandy Gallop, Queensland.

Sxitr, R. Percy, M.D., M.R.C.S., appointed Assistant Medical Officor to Bethlem Royal Hospital.

PRIZE DISSERTATIONS.

Competitors for the present year are requested to forward these to the President, Dr. H. Rayner, The Asylum, Hanwell, W., on or before 30th June next. T'he conditions of the competition are printed in the "Journal of Mental Science" for 1883 , at p. 664 .

\section{THE ANNUAL MEETING.}

The Annual Meeting will be held at Cork on Tuesday, 4th Angast. Members intending to be present are requested to send their names as early as possible to the Secretary for Ireland, Dr. Maziere Courtenay, Distriot Asylum, Limerick. 